California State University, Monterey Bay

Digital Commons@ @ CSUMB

$2-2015$

\title{
SMEs in their Own Right: The Views of Managers and Workers in Vietnamese Textiles, Garment, and Footwear Companies
}

Angie Tran

California State University, Monterey Bay, atran@csumb.edu

Søren Jeppesen

Copenhagen Business School

Follow this and additional works at: https://digitalcommons.csumb.edu/sbgs_fac

Part of the Social and Behavioral Sciences Commons

\section{Recommended Citation}

Tran, Angie and Jeppesen, Søren, "SMEs in their Own Right: The Views of Managers and Workers in Vietnamese Textiles, Garment, and Footwear Companies" (2015). SBGS Faculty Publications and Presentations. 15.

https://digitalcommons.csumb.edu/sbgs_fac/15

This Article is brought to you for free and open access by the Social Behavioral and Global Studies at Digital Commons @ CSUMB. It has been accepted for inclusion in SBGS Faculty Publications and Presentations by an authorized administrator of Digital Commons @ CSUMB. For more information, please contact digitalcommons@csumb.edu. 


\title{
SMEs in their Own Right: The Views of Managers and Workers in Vietnamese Textiles, Garment, and Footwear Companies
}

\author{
Angie Ngoc Tran · Søren Jeppesen
}

Received: 10 May 2014/ Accepted: 8 February 2015/Published online: 21 February 2015

(C) Springer Science+Business Media Dordrecht 2015

\begin{abstract}
This article contributes to the limited literatures on small- and medium-size enterprises (SMEs) and corporate social responsibility (CSR). Using an institutional theoretical framework, we analyzed fieldwork interviews with twenty SMEs and perspectives of 165 SME managers and workers in textiles, garment, and footwear industries, the most important wage-earning sector in Vietnam. Having understood in the context of a developing "market economy with socialist orientation" (thus a "Southern perspective"), we find that socially responsible practices and expectations developed long before the arrival of CSR as a western concept and an MNC agenda. While identifying and contributing ideas concerning forms of "informal" CSR practices-influenced by social and cultural expectations-to the CSR/SME literature, we are conscious of the mixed effects of these practices and the ongoing nuanced negotiations between workers and managers in these SMEs. In our research, we found that it takes both domestic and international stakeholders to improve labor conditions in Vietnam under the banner of CSR.
\end{abstract}

Keywords Socialist Vietnam - SME managers and workers · Formal and informal CSR practices - Institutional theory $\cdot$ Labor-management-state relations

\footnotetext{
A. N. Tran

Global Studies Department, Social, Behavioral and Global Studies Division, California State University, Monterey Bay, USA

e-mail: atran@csumb.edu

\section{S. Jeppesen $(\bowtie)$}

Department of Intercultural Communication and Management, Center for Business and Development Studies, Copenhagen Business School, Frederiksberg, Denmark

e-mail: sj.ikl@cbs.dk
}

\section{Introduction}

Small- and medium-size enterprises (SMEs) ${ }^{1}$ often account for up to $90 \%$ of all registered firms in an economy, and even more if the informal sector is included. In addition, SMEs are important providers of employment and producers of a large share of total industrial output in developing countries (Spence et al. 2003; UNEP 2003; Luetkenhorst 2004). Still, we have limited knowledge of corporate social responsibility (CSR) in SMEs compared to that of large firms (Jenkins 2004; Morsing and Perrini 2009; Laudal 2010). There is even less knowledge of what SMEs actually do in terms of CSR activities: why they chose specific types of activities, or about the implications of their actions (Jeppesen 2004; Vives 2006; Jamali et al. 2009; Skadegaard Thorsen and Jeppesen 2010).

In this article, we start with the idea that CSR can be viewed as the societal expectations of businesses at a given time (Frynas 2009). More specifically, we adopt Blowfield and Frynas' understanding of CSR as companies having a responsibility: (a) for their impact on society and the natural environment, sometimes beyond legal compliance and the liability of individuals; (b) for the behavior of others with whom they do business (e.g., within the supply chains); and (c) to manage their relationship with the wider society, whether for reasons of commercial viability or to add value to society (Blowfield and Frynas 2005, p. 503). To exemplify this approach, we focus on labor-

\footnotetext{
${ }^{1}$ No single definition of SMEs exists because governments, international organizations, and business associations represent different economic and political interests and goals that require language and structural differences in terminology. In this article, 'SMEs' are defined as 'registered entities having at least five employees and no more than 299 employees,' based on the official definition of SMEs in the textile, garment and footwear sectors in Vietnam.
} 
management relations, bringing in the voices of managers and workers in SMEs in the context of their formal and informal CSR practices in the Vietnamese textiles, garment, and footwear manufacturing sectors.

It has been argued that the CSR agenda is 'Northern, MNC dominated' (Blowfield and Frynas 2005; Newell and Frynas 2007) and lacks perspectives from the Global South's developing nations, including their communities and workers (Prieto-Carron et al. 2006) and local SMEs' perspectives (Fox 2005). We agree with these critical perspectives, which highlight the importance of context (Blowfield and Frynas 2005; Blackman 2006b; PrietoCarron et al. 2006; Jamali et al. 2009; Jamali and Neville 2011; Khan and Lund-Thomsen 2011) and the tensions inherent in CSR due to it being a western concept introduced by developed countries (Blowfield and Frynas 2005). Indeed in developing countries, CSR might not be known (Newell and Frynas 2007); it might be considered an alien concept (Jamali et al. 2009) or viewed as part of a 'western imperialist agenda' (in Khan and Lund-Thomsen with reference to Pakistan 2011).

The literature on CSR in SMEs, regardless of whether it concerns a developed or developing nation, tends to focus on what SMEs 'should do with regard to CSR' and is based on what large firms do (Laudal 2010). Few of these contributions address SMEs in 'their own right' (Jenkins 2004), but even then, SME perspectives are not included in these studies (Williamson et al. 2006), or the SME studies lack theoretical application (Lepoutre and Henne 2006; Jamali et al. 2009). Even fewer studies focus on SMEs and CSR in developing countries (Moore and Spence 2006; Jamali et al. 2009; Prieto-Carron et al. 2006; Jeppesen and Lund-Thomsen 2010).

Given this paucity of research, our paper contributes to existing studies that examine SMEs in 'their own right' and acknowledges the less-formalized or informal way of carrying out CSR practices (Whalley 2000; Jenkins 2004). As such, we focus on both formal and informal CSR practices to gain a fuller understanding of what CSR means to SMEs in a developing country context. Informed by the existing literature, we examine formal practices (such as occupational safety and health, labor standards, working conditions, and environmental conditions). We also discuss various forms of informal practices such as loans provided by management to workers, the provision of extra holidays or time off to take part in important family events such as marriages and funerals, and contributions by the SME to local community groups, churches and sport clubs. However, this study also examines the implications of informal practices-which existed long before CSR was introduced in Vietnam-of workers and managers. We ask: To what extent are the informal practices consistent with the real intent of CSR (as defined above)? And to what extent do they perpetuate paternalism?
We selected the textiles, garment, and footwear sector for three reasons: (1) this sector is the largest wage-earning sector in Vietnam, consisting of several thousand SMEs, and thus it allows us to examine the implications of both formal and informal practices; (2) this sector employs over two million workers (mostly women) and gives us the opportunity to showcase most-often invisible and rarely heard voices of the workers and managers who manufacture apparel and shoes for the world, and (3) the sector exemplifies the inner workings of four levels of the global supply chains in a country that ranked seventh in total world garment exports in 2011.

Understanding context is vital to understanding CSR practices undertaken by SMEs in developing countries. Thus, we contribute to the few studies that have focused on "Southern perspectives" (Jeppesen 2004; Tran 2011) by including on-the-ground perspectives of workers, trade unions and government officials in addition to owners and managers.

Scott's approach to institutional theory (Scott 1995/ 2001) provides our overall analytical framework, and we recognize a need for theoretically informed studies of SMEs and $\mathrm{CSR}^{2}$ such as institutional theory for this endeavor (as mentioned in Jamali et al. (2009). Based on Scott's three-pillar framework, we explain (a) what relevant regulatory, normative and cognitive institutions exist in Vietnam; (b) how Vietnamese managers in textile/garment/footwear (TGF) SMEs understand and practice CSR; and (c) how workers in these SMEs understand and practice CSR.

The article is structured as follows. First, we critically review the existing literature on SMEs and CSR and establish a broad-based perspective on CSR that distinguishes between formal and informal CSR practices. Second, we apply Scott's framework to the case of Vietnam, outlining the three pillars, and discuss the methodological framing of the study. Third, we present our findings. In this section, we hear the voices of managers and workers concerning the meaning of CSR and their real-life practices, ${ }^{3}$ this section is organized following Scott's regulatory, cognitive and normative dimensions. We conclude with a discussion of our findings and an assessment of the contributions of the study before ending with some policy recommendations.

\footnotetext{
${ }^{2}$ See Jamali et al. (forthcoming), an editorial to the special issue on SMEs and CSR in Developing Countries in Business and Society.

3 Please note that the missing articles and grammatical errors found in the translations are because they are taken verbatim from shorthand responses of both managers and workers in the questionnaire, which were then translated verbatim to English.
} 


\section{Literature Review}

Influenced by the mainstream CSR agenda (see above), numerous sources discuss the business case for CSR in SMEs and argue in favor of implementing formal CSR practices in SMEs. We suggest, along with other scholars who have expressed a critical view of the business case for CSR, a need to address the lack of SME perspectives in the literature. This includes the need to bring in the views of workers and to reduce the knowledge gap regarding the informal CSR practices that SMEs undertake (Jenkins 2004; Fox 2005; Murillo and Lozano 2006; Fassin 2008; Jamali et al. 2009; Jeppesen et al. 2012).

The studies that have investigated CSR in SMEs have concentrated on the 'business case' for SMEs as formal practices in global supply chains, ensuring quality products for end consumers, but not necessarily upholding labor standards for workers Raynard and Forstater (2002), World Bank (2003), Luetkenhorst (2004) and Luken and Stares (2005). For instance, Raynard and Forstater discuss how CSR can become relevant to SMEs in developing countries. They investigate the 'business case' for CSR in SMEs and develop a framework for 'small business responsibility' with reference to quality management systems (2002). Luetkenhorst states that 'SMEs... need to be provided with the tools to monitor and report on their own CSR performance and to continuously improve that performance' (2004, p. 166).

Many scholars criticize SMEs for not engaging in CSR and assume that they 'should do CSR,' specifying the (formal) CSR practices that SMEs should undertake. Singh, Kundu and Forstater (2005) argue that SMEs will gain from CSR in respect to turnover, productivity and/or number of clients. Luken and Stares (2005) suggest that the SMEs should be motivated to carry out environmental and social improvements because of the potential gains they receive as suppliers to MNCs. Other authors show how SMEs can be pressured or encouraged to adopt codes of conduct, acquire CSR standard certifications, and/or produce CSR reports (Williamson et al. 2006; Kumari 2008).

The emphasis on formal CSR practices is questioned by others. Fox stresses that 'conventional drivers for CSR are ...likely to have relatively little or no relevance to SMEs' $\left(2005\right.$, p. 6). ${ }^{4}$ Fassin argues that the quest for the formalization of CSR practices in SMEs rests on misunderstandings and fallacies (2008). ${ }^{5}$ Jenkins finds that the

\footnotetext{
${ }^{4}$ Instead, he points out that 'there may be drivers based on a sense of rootedness within a particular community ... or other social and cultural norms and experiences' (Fox 2005, p. 6).

5 Among the fallacies, Fassin (2008) lists (a) CSR is worthless without formalization, (b) SMEs do not report on CSR and hence do not have CSR, and (c) that the CSR approach of large companies can be used by SMEs (pp. 367-368).
}

theoretical approaches to CSR are biased toward 'large firms' perspectives' while assuming that SMEs are simply 'smaller versions' of large firms. Instead, she argues in favor of viewing SMEs 'in their own right' when dealing with CSR (Jenkins 2004). In fact, limited attention is paid to how SMEs can afford to practice CSR. SMEs often operate on low profit margins, so when 'the business case for CSR' is absent or too difficult to achieve economically, SME managers become reluctant to invest funds to meet CSR standards (Skadegaard Thorsen and Jeppesen 2010). Finally, it is important to pinpoint the unequal power relations among the relevant stakeholders in the context of CSR (Prieto-Carron et al. 2006).

Vives (2006) investigates formal and informal CSR practices in SMEs in different Latin-American countries. He highlights a number of informal practices (providing loans to employees, giving donations to local communities and churches) and shows how cultural norms and values influence CSR practices. As Vives points out, SME managers often are motivated to undertake CSR activities in response to cultural and religious issues due to a sense of personal or religiously inspired ethics concerning SMEs' engagement in CSR (Vives 2006). ${ }^{6}$ Jeppesen (2004) provides another example of such an SME perspective from small manufacturing firms in South Africa. Based on three in-depth firm studies, he shows how a combination of what is termed 'firm-internal' and 'firm-external factors' influence CSR practices. The firm-internal factors include the resources and capabilities that SMEs can devote to CSR practices and how the management-worker relations influence these practices. The firm-external factors include the pressures on the SMEs to conduct CSR, whether regulatory (from clients and government), normative (from industry and history) or cultural (from traditions, norms and values).

Most studies tend to derive the information from the managers of MNCs without corroboration from the SMEs (World Bank 2003; Blackman 2006a, b); only a few studies examine CSR from the SME perspective, and they still do not acknowledge the difficulties these businesses face (Whalley 2000; Jenkins 2004; Skadegaard Thorsen and Jeppesen 2010).

We argue that CSR needs to be investigated in a more inclusive manner that centralizes on 'Southern perspectives' in order to overcome the bias in the literature. We need to recognize significant interactions among the key stakeholders within SMEs, including workers, labor unions

\footnotetext{
$\overline{6}$ The literature on SMEs and CSR has also highlighted the contextspecific nature of SMEs' engagement in CSR, including the community embeddedness of many CSR activities (Fox 2005; Fuller and Tian 2006; Russo and Tencati 2009).
} 
and government officials, going beyond just managers/ owners (Jeppesen 2004; Tran 2011; Jeppesen et al. 2012).

Jeppesen argues the need to bring in insider perspectives-from owners, middle managers and workers-and to highlight the similarities and differences in how CSR is perceived within and among the different groups (Jeppesen 2004). ${ }^{7}$ In her study of CSR in Vietnam, Tran found that the existing studies (on large and small firms) tend only to present the perspectives of management and the state. Thus, she argues for the need to involve workers in external assessments of the impacts of CSR (Tran 2011). In a study of 124 suppliers of the US and European garment and footwear brands, Kim (2012) found that complementarity between state and transnational private regulation, which can supplement weak public law enforcement, introduces labor laws into code enforcement and raises workers' awareness of what management owes them and what rules exist. While this study seems to focus on large factories, our paper focuses on SMEs in the textiles, garments and footwear (TGF) industries in order to shed light on various combinations of state and private regulation and their effects on compliance with CSR as officially defined, and what initiatives SME managers have implemented when these official regulatory institutions have not covered such topics. When we include different perspectives on CSR from SMEs, we open up the possibility for a more in-depth understanding of the dynamics within these firms. ${ }^{8}$

For an illustration of the flow in the investigation, see Fig. 1 below.

\section{Theoretical Framework}

Institutional theory gives us an analytical tool to discuss how different institutions affect SMEs and their practices in developing countries, as acknowledged by other scholars (Jamali et al. 2009). Of the three main strands of institutional theory (comparative neo-institutionalism, new-economic institutionalism and new organizational institutionalism), we found new organizational institutionalism to be most relevant because it allows us to analyze how individual actors-workers and managers/owners-interact both inside

\footnotetext{
${ }^{7}$ Referring to this phenomenon, Whalley says that 'many cultures exist within SMEs' (2000, p. 120).

8 This issue entails additional dimensions that we will not discuss in this article. In particular, that existing contributions on SMEs and CSR tend to present SMEs as a monolithic type of firm and/or as one homogeneous unit or entity. The contributions often refer to SMEs as if this very large group of firms had similar characteristics. However, SMEs differ in size, type of activity undertaken, management style, markets (Whalley 2000; Murillo and Lozano 2006) and choice of CSR practices (Scott 2000; Vives 2006). Further assessment of the differences between SMEs constitutes an important future research area.
}

an enterprise and outside in the communities, reflecting the norms and belief systems that are practiced at the societal level. On the other hand, the comparative neo-institutionalism (Willmott 2011; Hotho and Pedersen 2012) strand does not add value to our study because it focuses on institutions at a societal level, and the new-economic institutionalism strand is concerned with conceptual development from a rationalist, formalistic and quantitative perspective.

There are variations within the new-organizational institutionalism strand. DiMaggio and Powell (1983) focus on how institutional pressures affect the actions of organizations and individuals in these organizations and the power of the actors involved. ${ }^{9}$ This perspective requires interviews with the corporate buyers (or the clients/buyers of SMEs), who are not the focus of our study. Laudal (2010) presents an interesting application of this perspective of 'global dissemination' of CSR among SMEs. He hypothesizes that 'coercive isomorphism' seems to be the most important way of understanding the uptake of CSR among SMEs. While we share Laudal and other scholars' view that SMEs are likely to adopt CSR because they are forced to do so by external pressures (from MNCs and other actors) we argue that other internal factors are equally important.

In contrast to these perspectives, we actually take "institutional pressures" (such as government policies or corporate buyers' regulations) as given and engage directly with SME owners and workers to understand how they respond to those pressures at the firm level. We do not focus on the interplay between institutions and SME strategies. As such, Scott's framework (within the neworganizational institutionalism strand) helps us to explain the behaviors and actions of SME labor and management, in particular, to analyze their understandings of CSR and their CSR practices (both formal and informal).

Scott provides a three-pillar structure to analyze the key aspects of social institutions, defined as 'social structures that have gained a high degree of resilience,' and how they affect firms and their practices (2001, p. 48). The three pillars are (1) 'regulatory' (laws, regulations, and government policies); (2) 'normative' ('normative rules' that introduce a prescriptive, evaluative, and obligatory dimension into social life'); and (3) 'cognitive' ('the shared conceptions that constitute the nature of social reality and the frames through which meaning is made') (Scott 2001, p. 57. See also Amine and Staub 2009). This multi-level structure

\footnotetext{
9 Other perspectives such as those of Peng and others (Peng 2002, 2003; Amine and Staub 2009) focus on market-oriented institutional transitions - formal and informal - and how they affect firm strategies and decision-making. However, these perspectives are not relevant to our case because we did not focus on the interplay between institutions and firm strategies, nor did we seek to engage the formal institutions by interviewing the representatives of such institutions.
} 


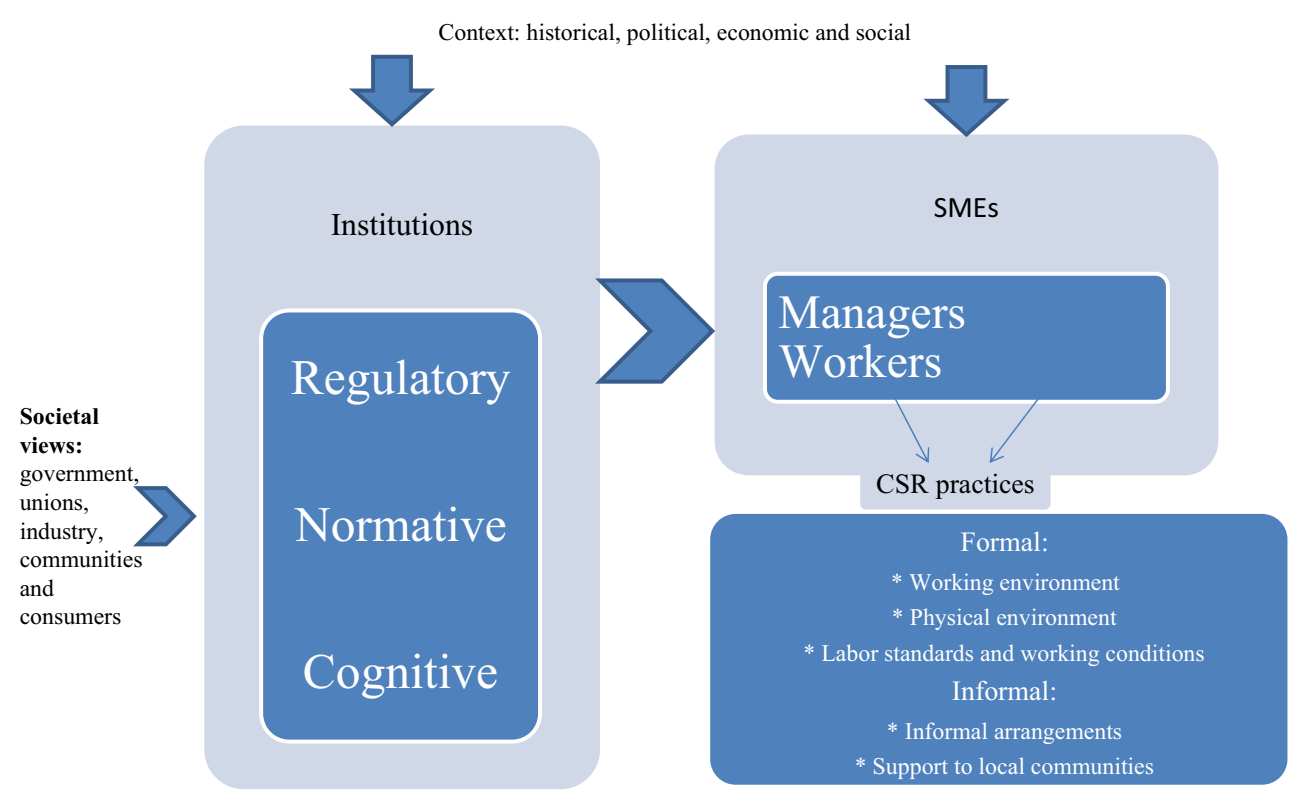

Fig. 1 Flow chart on process of investigating formal and informal CSR practises among managers and workers in TGF-SMEs in Vietnam

embraces history which is important to the analysis of socialist Vietnam transitioning from a command economy to a market system fully integrated into the global capitalist economy.

First, factors in the regulatory system can either encourage or discourage CSR practices through incentives or disincentives - by way of providing or restricting access to resources. Promulgating healthy and safety practices may highlight the importance of certain standards in the working environment in SMEs, which can be supported by stringent enforcement or undermined if limited or no enforcement takes place.

Factors in the normative system reflect societal belief systems which reaffirm the expectations that one should have decent working conditions, job security and benefits, and a clean environment. We also note that 'societal views' should include the views of consumers, local communities, unions etc. ${ }^{10}$ However, given the scope of this paper, we chose to focus on the views of owners/managers and workers only in the TGF enterprises. We have supplemented these views with formal and informal interviews with representatives from the local unions and state officials.

As for the regulatory pillar, we consider both government provision (such as social welfare, public health and education) and private regulation (such as services and benefits to employees). In cases of limited resources and lack of willingness, the government tends to leave these

\footnotetext{
${ }_{10}$ A stakeholder perspective would similarly include a range of views of importance to the SME (see e.g. Freeman 1984). However, the focus revolves around the firm (MNC) actions-the key stakeholder-not the suppliers or the workers.
}

responsibilities to the companies, which are then expected to provide them to employees. Moreover, if the state does not enforce the regulation on labor standards, such as minimum wages and health insurance, then the firms are supposed to do so. But while large firms are assumed to have the financial resources to set up a health clinic on the factory premises, SMEs have far fewer resources to do so.

While Scott's framework is relevant and useful for our study, we acknowledge its limitations and suggest ways to overcome them. First, in his discussion of the 'normative system,' Scott presupposes a particular western political economic system, which is different from the case of Vietnam. Second, his perception of 'societal views' is complex and broad, and thus difficult to establish in one study. Therefore, we choose to focus on the views of key stakeholders that are rarely heard, such as the SMEs' owners/managers and workers, and to omit other stakeholders listed above, which might be included in subsequent studies. Third, recognizing the effects of unequal power relations in the global supply chains, we add critical perspective to Scott's framework (2001) when applying it to socialist Vietnam. In particular, we embed differential power relations in the multi-tiered global supply chains, and reveal the responsibility of large firms/MNCs toward their first-tier suppliers, and (second and third-tier) subcontractors often invisible to the MNCs, as well as MNCs' third-party auditors in the TGF industries.

As part of a normative formal system, MNCs, their firsttier supplier companies and their auditors, and industry associations set the standards or codes of conduct - for SMEs to follow. Training courses on the implementation of codes of conduct can increase awareness of the issues that 
the codes address: leading management to insist on using safety equipment and workers to realize the need to use it (even if it causes discomfort) and to demand safe working conditions. However, the code's requirements often propel the SMEs to spend money, such as to provide masks or build more toilets for workers, which they cannot afford even with incentives to comply.

The factors in the cognitive system, defined as 'people's cognitive structures and social knowledge' (Amine and Staub 2009, p. 200) are often the individuals' understanding and reasoning, which are influenced by both normative/belief systems and regulatory factors. Thus, there is an interconnection among these three factors-cognitive, normative and regulatory. So, a manager experiencing a lack of government (public) enforcement and knowing that competitors are not observing the law will be inclined to think 'Why should I do so?' And when managers do not follow stipulated practices, workers often think 'Why should we do so?' as well. On the other hand, certain religious beliefs and cultural practices will influence managers to give contributions to the local community and religious celebrations. In Vietnam, the 'Tet bonus' is an additional, 13th month wage given to celebrate the Vietnamese Lunar New Year and to support the families of migrant workers.

\section{Vietnam's Historical, Political and Economic Contexts}

We selected Vietnam as a case study because it allows us to examine how a transitional economy has influenced SME practices and the impacts of CSR. As is well-known, Vietnam has aspects of both socialist and capitalist systems. The 1989 disintegration of the Soviet Bloc and the collapse of the Eastern European market (Vietnam's major trading partners) led to a systemic shock for the Vietnamese economy with loss of trade, aid, loans, and commerce. Facing such difficulties, Vietnam opened itself to other markets, especially Japan, Association of Southeast Asian Nations (ASEAN), and the European Union. Since 1989, the Vietnamese state has called itself a "market economy with a socialist orientation" aiming to fulfill a "civilized and equitable" society. After several years of adjusting to the new global situation, Vietnam formally endorsed the market-based economy at its Party Congress in 1992. Further global integration took place with the end of the twenty-year US trade embargo in 1994, the US diplomatic relations with Vietnam in 1995, and Vietnam's accession to the World Trade Organization in 2007.

As found by Tran and Norlund (2014, pp. 16-17), Vietnam has not yet abandoned socialism in terms of industrial policies and progressive labor laws, but it faces the dilemma of a market-based economy: growth in trade and investment but limited value added to society. Vietnam continues to supply mainly low-skilled, low-paid labor force to the manufacturing sector in which SMEs are key (Tran and Norlund 2014, pp. 9, 11). Situated in this historical context, Vietnam's socialist legacy represents the dilemmas faced by a developing country that still has to respond to the workers who constantly remind the state and their institutions to uphold the socialist vision and social contract for their rights and entitlements (Tran 2013).

The Vietnamese state continues to enforce public regulation, but the division of labor between the state and the private sector is mixed. ${ }^{11}$ In the context of Vietnamese market socialism, we found a combination of state and quasi-state institutions that purport to regulate labor and environmental conditions. This combined regulatory structure has been entering into "environmental consultancy" service contracts with the MNCs who place orders with these SMEs. As discussed in the Regulatory System in the Vietnam Section, evidence shows that both SME managers and workers are put under pressure to comply with CSR codes of conduct and standards while most MNCs refuse to share the costs with those SMEs under a 'CSR heading. ${ }^{12}$

In the context of "market economy with socialist orientation," it is important to understand the function of the Vietnamese Chamber of Commerce and Industry (VCCI), a quasi-state business/management association, which is in charge of implementing/mainstreaming CSR in Vietnam. This sets the Vietnamese case apart from those of nonsocialist Asian countries such as Korea or Taiwan. Since the Prime Minister Decision No. 123 in 2003, the VCCI is the principal association that is supposed to represent thousands of both foreign and domestic employers, including small and medium enterprises in the private sector, as well as joint-stock company members that were formerly state-owned enterprises. The VCCI is run mostly by retired state officials or party members who have close connections to the one-party government. In reality, VCCI only represents its members, not the whole private sector as stipulated by law. The VCCI does not have a nationwide presence, nor can it control the budgets of its member firms. ${ }^{13}$

\footnotetext{
${ }^{11}$ With regard to the relevance of Rawls (2001) for Vietnam and the study, please kindly review Appendix 2 for an extended discussion.

12 Similar to Rawls, Arnold and Hartman draw on Kant as they have the following point on MNC managers and their respect for workers: "One core ethical obligation of MNC managers is to respect their employees. To fully respect a person, one must actively treat his or her humanity as an end, and not merely as a means to an end. This means that it is impermissible to treat persons like disposable tools. The Kantian basis for this claim is well established (Arnold and Hartman 2006, p. 682).

13 Tran (2011), pp. 128-129; www.vcci.com.vn/sub/vbli/default.htm. Aaccessed October 2014.
} 
In Vietnam, the concept of CSR has been introduced from the top down by western governments and both national and global institutions (Tran 2011; Hamm 2012). The World Bank, the US, the ILO and MNCs have pressured the Vietnamese government to participate in CSR initiatives since 2002, and with increasing urgency between 2004 and $2006 .{ }^{14}$ In this context, the VCCI-not the Vietnamese labor union or any other NGO-has been appointed to be the key organization to manage and oversee CSR in Vietnam. ${ }^{15}$ VCCI has been working closely with UNIDO on "CSR: Adapt, Adopt, Improve CSR in Vietnam's SME" initiative, and they have been training CSR consultants to mainstream CSR as a "business case". ${ }^{16}$

Reviewing the reports of UNIDO (2002 and 2006) shows a mixed and incomplete picture of what VCCI has actually accomplished. In the 2002 UNIDO report, there is only one page dedicated to the case of Vietnam (Box 27: IBLF Business Links Programme), which stated the goals of the Vietnam Business Links Initiative (VBLI) to ensure healthy and safe working environment for workers, especially on the handling of chemicals, and measures to reduce noise, fumes and dust. The VBLI is led by a management forum, including the International Business Leaders Forum (run by sportswear companies such as Nike, Pentland and Adidas), international NGOs, the VCCI, the Viet Nam Leather and Footwear Association, and the Vietnam and British governments. While the stated goals to improve the business environment in developing and transitional economies-such as Vietnamare consistent with CSR intent, there is no evidence or concrete example of how the VBLI supports local shoe manufacturers to meet local environmental and health and safety regulations as well as the MNC social and environmental purchasing criteria. In the 2006 UNIDO report (with only 5 pages on the VBLI), while there has been some progress, there is still no labor representation on the steering and management committee in this primarily footwear/garment management forum and a lack of concrete details on the effects of this model. Except for some general statistics on the Management Support System and on the participation of the pilot footwear factories (60\% of factories in the footwear industry), there is no example, nor are there any voices from the participating managers and workers. ${ }^{17}$

\footnotetext{
${ }^{14}$ For example, the Ministry of Labor, Invalids and Social Affairs (MOLISA) worked with the ILO to conduct several preliminary studies of the impacts of CSR in Vietnam.

15 UNIDO: corporate social responsibility: implications for Small and Medium Enterprises in Developing Countries; UNIDO, Vienna, 2002; UNIDO: SME Clusters and Responsible Competitiveness in Developing Countries-AccountAbility with UNIDO, January 2006; (Hamm 2012).

$16 \mathrm{http} / / /$ vccinews.com/news_detail.asp?news_id=27693; http://www. csr-vietnam.eu/.

${ }^{17}$ UNIDO 2006, pp. 45-49.
}

The 2004 Action Aid Project on Raising Awareness on Corporate Social Responsibility for Small and Medium Size Enterprises in Cottage Industry focused on the responsibility of MNCs to the well-being of workers and the environment. The project has investigated the employment, the labor safety and working conditions in traditional (artisanal) villages in three provinces and cities in the North of Vietnam, and provided concrete and realistic recommendations on causes of poor compliance to labor and environmental regulations in these trade villages. However, the main focus is not on SMEs, but on the environmental and health conditions of villagers in these provinces.

In a study focusing on multinationals (MNCs) and their large suppliers, Tran (2011) found that CSR in Vietnam was largely tokenistic and pursued primarily for the sake of western MNCs, not of workers. The multilevel subcontracting nature of the global supply chain makes it very difficult to monitor suppliers and their contract factories for code compliance. Hence violations are rampant in supplier factories, with MNCs shirking their responsibilities to share the costs involved in the proper enforcement of CSR. In turn, the Vietnamese government has also failed to support CSR implementation in these large suppliers (Tran 2011), and there is no public CSR policy in Vietnam either (Hamm 2012).

\section{Methodology}

Our methodological approach combines and integrates exploratory with explanatory components. We draw on sources with a 'Critical CSR approach' (Blowfield and Frynas 2005; Prieto-Carron et al. 2006; Newell and Frynas 2007) for the exploratory part, and we use institutional theory (Scott 1995/2001) for the explanatory part.

Our selection of the survey and interview questions reflected the exploratory and explanatory components, including sensitivity to the country-specific contexts and the need to bring out voices of managers and workers. We asked questions to understand not just the formal practices of CSR, but also the informal practices initiated by the managers/owners of these SMEs. ${ }^{18}$ From June to

\footnotetext{
18 Examples of crucial questions asked to managers and workers include: (A) Do you/your firm monitor the usage of water, electricity and input materials? (B) Are the occupational safety and health procedures in your firm due to government regulation, formal certified systems, codes of conduct or your own system or practices? (Similar questions were asked regarding wages and labor standards), and (C) Does your company e.g. provide loans to the employees/workers, allow sick leave and/or absence to participate in funerals, family events etc, organize musical/cultural performances, donate book/magazines to companies and dormitories? See Appendix 1 for further information on all the questions asked and Jeppesen et al. (2012) for further information on the format of the questionnaires and
} 
December 2011, we interviewed managers and workers from twenty SMEs in the TGF industrial sector in Vietnam. ${ }^{19} \mathrm{We}$ conducted three rounds of data collection among the twenty SMEs ${ }^{20}$ resulting in a total of 165 interviews of which forty were with management (two interviews per company) and 125 with workers-108 from medium and 17 from small enterprises (see Table 1 below). ${ }^{21}$ The SMEs selected for interviews were all located in Ho Chi Minh City and its surrounding rural districts, localities with large industrial areas and a high concentration of SMEs in the TGF sector.

\section{Logic of Sampling}

We were able to collect a convenience sample, given the many constraints, thus we admit that there are some biases and we do not generalize our findings. The lack of availability of statistical information on the thousands of SMEs in Vietnam prevented us from conducting a more rigorous randomly selected sampling. However, even with this convenience sample, we had taken great care to meet the three criteria of size (small versus medium-size), markets (domestic versus international markets), and location (metropolitan versus non-metropolitan), and were able to point out some important patterns discussed in the findings sections. Overall, the constraints we faced were caused by many difficulties of doing fieldwork in socialist Vietnam.

$\overline{\text { Footnote } 18}$ continued

interview guidelines, and Sects. 2 and 4 in Jeppesen et al. (2012) for the reasons for focusing on these issues.

19 Among the 20 SMEs, seven were small and 13 medium-size; 17 had international markets, while 3 sold domestically; and 10 were based in the metro area, while 10 were based in non-metro areas (Jeppesen et al. 2012).

${ }^{20}$ See Appendix 1 and Jeppesen et al. (2012) Appendix 1 for further details.

${ }^{21}$ We were able to interview workers in 14 SMEs, and not in six factories. The key reasons were not because the owners want to 'hide' their practices, but precisely because, as second-tier suppliers, they were directly affected by the work pressure of manufacturing for global supply chains with workers who wanted to work overtime to make ends meet. The three medium factories did grant us management interviews and allowed us to interview their workers subsequently. But when we followed up on their promises, all three pleaded 'urgent delivery schedules' (to first-tier suppliers) for not allowing us time to interview their workers. Also, we could not interview workers in three TGF factories mainly due to the heavy work pressure of ontime deliveries and the piece-rate payment system. The interviews with managers and workers were conducted face-to-face in Vietnamese by field assistants whose first language is Vietnamese. All three questionnaires were translated into Vietnamese and verified by Vietnamese native speakers to ensure relevance to Vietnamese cultural contexts. In the data analysis phase, the information from the questionnaires was a) typed into Word documents from in-depth interviews (open-ended sections of the forms) and b) coded and typed into SPSS from the quantitative sections (Likert-scale typed questions and changes over time).
First, we had to rely on the cooperation and willingness of the SMEs-already stretched out with delivery schedules-so it is likely that the more compliant SMEs tend to be more willing to participate. Second is about the reality in socialist Vietnam: without proper connections to the local labor unions and local government officials (in both metro and non-metro areas) who work with these SMEs, we cannot obtain approvals to conduct interviews with the managers and the workers, whose voices are vital to our study.

An initial target of 20 SMEs was expected to be manageable, though the process of identifying SMEs in the TGF sector and securing their participation was very timeconsuming and more challenging than anticipated. Even with a team of seasoned and well-connected researchers, we had to make many phone calls to set up the initial interviews and more phone calls for follow-up visits to complete the surveys and in-depth interviews. The final sample of 20 SMEs included seven small-size and 13 medium-size firms, employing from 5 to 240 employees with an average of 67 persons per firm. 11 were located in the urban, industrial areas of Ho Chi Minh city (termed'metro'), while 9 or just less than half were located outside the metropolitan area (termed 'non-metro'). The vast majority of firms had been in existence for 6 years or more, while the age of the firms ranged from one to 25 years (see Table 2 below).

\section{Empirical Findings}

The key empirical findings can provide the big picture before moving to the analysis of the three institutional theory pillars (regulatory, cognitive and normative). Seventeen of the interviewed Vietnamese SMEs manufacture for foreign suppliers in global supply chains; only three companies produced for the domestic market.

A high reduction in employment among SMEs with little growth during 2011 indicates the lingering effects of the global financial crisis on socialist Vietnam, after it fully engaged in the global market system. The growth picture is ambiguous: half of the interviewed textile and clothing SMEs experienced growths in sales, while about a third had seen decline. However, the reduction in employment is clear: close to half the SMEs reduced their number of employees, only a quarter reported increases, and another quarter stated no change (see Table 3 above).

This reduction in hiring suggests two problems. First, these SMEs have been exposed to the global economy. The Vietnamese SMEs, in the bottom rung, can subcontract for either what we term 'East Asian intermediaries' (mostly large firms, primarily from Taiwan and South Korea) or directly to "end buyers/MNCs." The onset of the 
Table 1 Number of interviewed SMEs and number of interviews according to category

\begin{tabular}{ll}
\hline Categories & Numbers \\
\hline Total number of SMEs & 20 \\
Interviews with management (in-depth) & 20 \\
Interviews with management (survey questions & 20 \\
$\quad$ focused on changes in the last five years) & \\
Interviews with workers (in-depth) & 125 workers \\
& (in 14 SMEs) \\
Total number of interviews (managers and & 165 \\
$\quad$ workers) & \\
\hline
\end{tabular}

Source: Jeppesen et al. (2012)

Table 2 Descriptive statistics on the 20 interviewed SME in the TGF sector in Vietnam

\begin{tabular}{|c|c|c|}
\hline Size & 7 small & 13 medium-size \\
\hline $\begin{array}{l}\text { Employees (spread } \\
\text { and average) }\end{array}$ & $5-240$ & 67 \\
\hline $\begin{array}{l}\text { Location (metro or } \\
\text { non-metro) }\end{array}$ & 11 metro & 9 non-metro \\
\hline $\begin{array}{l}\text { Years of } \\
\text { Establishment }\end{array}$ & From one to about 25 years & $\begin{array}{l}85 \% \text { were } \\
6 \text { years or } \\
\text { older }\end{array}$ \\
\hline Market & 3 local & $\begin{array}{l}17 \\
\text { local }+ \text { export }\end{array}$ \\
\hline $\begin{array}{l}\text { Turnover (range } \\
\text { and average) }\end{array}$ & $\begin{array}{l}\text { From about } 10.000 \text { USD to } \\
\text { above } 700.000 \text { USD }\end{array}$ & 103.000 USD \\
\hline Ownership & $73 \%$ owned by single persor & or family \\
\hline
\end{tabular}

Source Jeppesen et al. (2012)

All SMEs were located in or around Ho Chi Minh City (former Saigon) in the Southern part of Vietnam

worldwide financial crisis at the end of 2008 began to impact Vietnam tremendously in 2009, especially the export-oriented TGF factories, due to the lower demand from Europe, the USA and East Asian countries. However, these linkages to the international market do not mean that these SME managers receive support from their foreign suppliers or MNCs to pursue formal CSR practices. ${ }^{22}$ Second, there is a long-term structural problem of labor fluctuation: migrant workers search around the city for jobs with perceived higher wages and/or better benefits (such as social, health, and unemployment insurance). According to workers' interviews, the main reason for them to move around in search of higher wages is the lack of a living wage (exacerbated by crippling inflation) and the lack of social, health, or unemployment benefits. They thought that higher wages could be found elsewhere, but interviews with managers revealed this to be a pipe dream because of

\footnotetext{
${ }^{22}$ More discussion on local initiatives to help themselves will be discussed in the Cognitive and Normative sections below.
}

the existence of a regional equilibrium average wage for low-skilled workers; workers are therefore not likely to get higher wages by moving around the city. This has led to the labor fluctuations lamented by many managers, and it provided an important context for understanding workerowner relations at the cognitive and normative levels. But, first we will address what types of regulatory regimes exist in Vietnam and how they affected CSR practices according to both managers and workers.

\section{The Meaning of the Regulatory System in Vietnam}

The regulatory system revolves around compliance, its legitimacy, mechanisms and indicators (Scott 1995, pp. 34ff). With 'expedience' as the basis of compliance, the regulatory system's mechanism is often of a coercive nature, with rules and laws, the foundation for their legitimacy being that they are legally sanctioned (Scott 1995, pp. 35ff). The regulatory pillar consists of three key actors: governmental agencies, corporate buyers, and the supplier companies. We consider the regulation of corporate buyers and their first-tier suppliers to be private, and the Vietnamese state's mandatory regulation as public. In Vietnam, there are three levels of regulation which affect the practices of managers/owners and workers: the private (transnational), state (or public), and company/factory levels.

First, on private regulation: $85 \%$ of the 20 textile/garment/footwear factories we interviewed manufacture for export. ${ }^{23}$ The majority (14 out of 17) of SMEs reported having to comply with many forms of transnational private buyers' regulation.

As second-tier suppliers in the bottom rung who are subcontracting for larger suppliers (see the Empirical Findings section), many SMEs have to comply with several buyers' standards and regulations because they often take orders from many corporate buyers or East Asian intermediaries.

Overall, the reaction of SME managers to this type of private regulation is expedient and compliant in order to export their products. As one manager in a medium-size garment firm expressed it: '.. we are required to implement CSR. If we do not, we would have to close our business.' But East Asian intermediaries do not share the costs, and the end buyers or MNCs turn a blind eye to manufacturing at this lowest rung of the global supply chain. Thus, the factories themselves have to pay for these inspections in order to be able to export their assembled products. The situation can become untenable when the

\footnotetext{
23 The six factories that did not state any private buyers' regulation include four small and two medium factories.
} 
Table 3 Development in sales and employment among interviewed SMEs in the textile, garment, and footwear (TGF) industries in Vietnam

\begin{tabular}{lll}
\hline $\begin{array}{l}\text { Sales/ } \\
\text { employment } \\
\begin{array}{l}\text { Type of } \\
\text { development }\end{array}\end{array}$ & $\begin{array}{l}\text { Development in } \\
\text { sales }(n=20)(\%)\end{array}$ & $\begin{array}{l}\text { Development in no. of } \\
\text { employees }(n=20)(\%)\end{array}$ \\
\hline Growth & 50 & 27 \\
Stable & 17 & 28 \\
Decrease & 33 & 45 \\
\hline
\end{tabular}

Source Jeppesen et al. (2012)

East Asian intermediaries and corporate buyers or MNCs require certification of different codes of conduct, which can be very costly for SMEs to comply with. ${ }^{24}$ Management at a medium-size factory making leather purses and gloves explained: 'Funds are needed to carry out these [CSR] responsibilities. Due to the fact that this is our company's responsibility, we cannot ignore this CSR cost, but have to include it in the final price of our products.' In other words, by absorbing this cost, they lose their price competitiveness compared to other factories that spend nothing on CSR.

Sometimes, the buyers pay for and send in third-party global monitors or auditors (such as Intertek, SGS or FLA with branches in Vietnam) to carry out factory inspections; sometimes the buyers themselves (such as the Japanese consumers' association) come down to the factories to inspect. What they inspect is a mixed bag. Our findings show that this type of regulation focuses primarily on ensuring that the quality, safety, and performance of the manufactured products meet the relevant standards of the end consumers (in the developed, importing countries), not the labor standards of the workers who have manufactured those very products. For instance, the final products of one medium-size garments factory must meet the Eco Tex standards ${ }^{25}$, otherwise it cannot export to the EU. At a medium shoe factory, one representative emphasized that 'we must follow what our buyers regulate; otherwise, we cannot export our shoes.' In this case, SGS was the transnational auditor. On their website, entitled $S G S$ in Vietnam, this company advertises its services (inspection, testing, certifications, and verification) to 'reduce risk and improve productivity' for its customers (the corporate buyers), but it never once mentions labor or workers. ${ }^{26}$ One

\footnotetext{
${ }^{24}$ Skadegaard Thorsen and Jeppesen (2010), deal in depth with the many challenges that this phenomenon, sometimes called 'code mania', represent for local suppliers, including SMEs. As the same authors point out, this also leads to the exclusion of SMEs from the value chains.

${ }^{25}$ For more information on the standard, see: http://live-in-green. com/products/bedding/eco-tex.html
}

representative at another medium-size garment factory said: 'Foreign buyers from Hong Kong ${ }^{27}$ often come to the factory to assess the quality of the working environment. Otherwise, foreign buyers hired global auditing companies based in Vietnam with mainly Vietnamese employees. For instance, Intertek did come to audit our factory.' A closer look at Intertek shows that its main focus is to 'evaluate the quality and qualifications of products' and 'suppliers' capability.' Nowhere on their website were the words 'workers, working conditions' or 'labor standards' mentioned. ${ }^{28}$

Occasionally, private regulation can bring about some positive effects for workers, especially on work safety issues. For instance, the popular Japanese ' $5 \mathrm{~S}$ ' system (including screening, organizing, cleanliness/hygiene, caring and readiness), ${ }^{29}$ which is required in any factory that assembles products to be exported to Japan, can improve work safety for workers. A representative from a mediumsize kimono factory said: 'The Japanese consumer association first sent their representatives to visit and inspect our factory, returned to Japan to report the findings to their members, then after [everyone] was satisfied [with what they witnessed on the factory floor], they signed the contract with us.' Other common work-safety issues include adequate factory space and an appropriate number and cleanliness of restrooms for workers. In a medium garment factory, one union representative said: '[in the past] due to our factory facility not meeting the buyer's standards (80\% export to the USA), we lost the direct contract signed with that buyer and ended up subcontracting (being in the bottom-rung) for another buyer. But, in the near future, our company is building a factory occupying over $2000 \mathrm{~m}^{2}$, and (when it is ready) we will transfer all of our workers to the new facility. Then, the conditions will be more positive (to regain the direct contract signed with the first buyer).' Of course, while these examples are not representative and the buyer factor can definitely play a role (with the USA and Japanese being represented here), they show the potential for the positive influence of private regulation on improving factory facilities and work safety, a win-win situation for both labor and management.

Second, state regulation exists in a mixed structure, encompassing both state and quasi-state agencies, and it focuses primarily on environmental standards and the working environment, not on working conditions. Overall, this combined structure charges two types of fees: state

\footnotetext{
${ }^{26}$ http://www.sgs.vn/en/Our-Company/About-SGS/SGS-in-Brief/ SGS-in-Vietnam.aspx, accessed 12 June 2013.

27 What we call 'East Asian intermediaries' in this article.

28 http://www.intertek.com/news/2010/11-16-audit-services-alibaba/.

29 This means: Screening (Sàng Lọc), Organizing (Sắp Xếp), Cleanliness/Hygiene (Sạch Sẽ), Caring (Săn Sóc), Readiness (Sẵn Sàng).
} 
management fees (from the state sector: the Department of Natural Resources and Environment, DONRE), and service fees (from the quasi-state agency: Institute of Water, Resources, Environment, Technology, IWRETE). ${ }^{30}$ DONRE is a government environmental entity which has jurisdiction over both city/province and district levels; it manages natural resources (including land, water, minerals, and marine resources) and the environment of the administrative location in which it resides. ${ }^{31}$ DONRE charges management fees to monitor SME compliance with state environmental laws by visiting factories and filing reports. On the other hand, IWRETE, an environmental consultancy, charges service fees as stipulated on the contracts signed with foreign buyers (MNCs who place orders with SMEs), or with SMEs directly, or even in contracts signed with a government entity. ${ }^{32}$ As such, IWRETE service fees vary and depend on the scope, scale, and complexities of what need to be monitored at the SME premises (such as toxic materials, waste water, dust, or noise).

Six out of twenty (30\%) TGF factories reported obstacles that are related to state regulations on environmental issues and the costs associated with compliance with state regulations. These problems range from unclear state instructions to time-consuming paperwork requirements to inconsistent state regulation. For instance, an owner of a medium-size garment factory complained that 'We are building an environmental project according to the request of Ho Chi Minh City DONRE. The monitoring report is done once every six months. This is a costly endeavor because we do not completely understand the instructions and have to hire other [consultancy] services (at about eight million VND).' The garment factory owner then suggested that DONRE should provide consistent state instructions and recommendations to different service agencies. Another manager from a medium-size garment factory complained: 'It is time consuming to produce environmental reports for official agencies.' Other managers complained about the lack of consistent government enforcement, leading to compliant companies being at a disadvantage compared to those which did not comply as phrased by one manager of a medium-size garment factory: 'At the moment, our company spends an annual amount of

\footnotetext{
${ }^{30}$ Correspondence with Dr Huynh thi Ngoc Tuyet and Ms Nguyen Minh Chau, September 2-7, 2013. Also, in http://www.ust.vn/trade_ detail.asp? trade $=10585$ andcat $=19 \mathrm{andp}=95$ (Accessed September 8, 2013).

31 The city people's committees govern DONRE administratively, and the Ministry of Natural Resources and Environment directs and supervises DONRE technically.

32 IWRETE is Viện Kỹ thuật Tài Nguyên Nước và Môi Trường in Vietnamese. It is an environmental consultancy institute that belongs to the Vietnamese Science and Technology Association (VUSTA or Liên Hiệp Hội Khoa Học and Kỹ Thuật in Vietnamese).
}

four billion VND on chemicals used for processing [or treating] waste, while many other companies do not do this. If that four billion VND is not spent on waste treatment chemicals, then it can be used for other things such as expanding production. At the same time, we have to keep our product prices the same as those of other companies!

If these costs are not shared by the corporate buyers or first-tier East Asian suppliers, then SMEs have to absorb them in order to receive the garment or footwear contracts, in addition to the costs of treating waste materials themselves. Some complained about the lack of funding for being compliant. For instance, the owner of CT garment, a medium-size garment factory, lamented: 'The waste water treatment system is expensive. It costs about 300 million VND (about US \$15,000), and it is installed once and for all... During inspection, the government can impose a fine of up to 500 million VND.' A manager from another medium-size garment factory concurred: 'Funds are required to carry out these responsibilities,' and accordingly the SMEs have to add these costs of CSR to their product prices. In short, the proliferation of state and quasi-state regulations can be a cost to SMEs with ambiguous results.

State regulation on labor standards also has many shortcomings. Overall, few labor inspectors go to factories to monitor labor standards as stipulated in the Labor Code, this being consistent with a finding by Kim (2012). ${ }^{33}$ Seven out of twenty (35\%) TGF factories reported obstacles related to state regulation of labor standards, ranging from often cited concerns such as stable wages, a proper working environment and social and unemployment insurance, to some lesser-known issues such as income tax policy and residence permits for migrant workers. For instance, a manager in a medium-size garment factory suggested that the income threshold for income tax should be raised: 'The minimum wage level that is subjected to income tax should increase. Right now, you have to pay income tax for a wage of four million VND (per month), but this wage level is not enough to cover all living expenses, and is not much.' In another medium-size garment factory, the manager brought up a major concern of migrant workers, namely that the majority of them are working in factories manufacturing for export where: 'Migrant workers with temporary resident certification will receive a housing subsidy of VND 300,000 , and 200,000/month without certification.' While these amounts were small, they were critical to these poor workers' survival. Also, several small factories complained about the lack of government attention to their needs. For instance, the manager of a small shoe factory/workshop

\footnotetext{
${ }^{33}$ Her interview with a VGCL official shows that there were only four or five inspectors in Ho Chi Minh City to monitor nearly 40,000 enterprises that have been established there since 2000 (Kim 2012, p. 288).
} 
suggested: 'Social insurance specialists can provide us with clear explanations so that we can relay this information to workers when they inquire about social and unemployment insurance.' In a small garment factory, the manager said: 'We are on our own; since this is a small company; we have not received any attention from the local government.'

Third, company and factory regulation is very popular among the SMEs. Regardless of the existence of either state or global private regulation, most factories we interviewed have their own regulations. Surprisingly, almost $70 \%$ of the workers we interviewed reported seeing company or factory regulations posted in the factory premises, though they understood them as codes of conduct. We will provide concrete evidence of this in the cognitive section, but overall most interviewed workers believed that CSR is a set of regulations that tells them what to do and what to avoid on the factory floor. Only a handful of workers understood that it is about the responsibility of employers, not themselves, to improve labor standards and their working conditions.

But how do managers and workers understand CSR? And how do the cognitive institutions affect their understanding and expectations?

\section{The Meaning of the Cognitive System in Vietnam}

First, we start with empirical findings on managers' knowledge of the term CSR and their understanding of social responsibilities. Second, we bring in workers' perspectives on CSR and their expectations. Third, we compare and contrast the cognitive schemas of managers and workers.

As shown in Table 4, about $60 \%$ of Vietnamese managers in SMEs stated that they are aware of and know the CSR concept. Interestingly, when asked about their companies' responsibilities, all interviewed managers/owners felt responsible for labor standards, working conditions, and working environment, and $90 \%$ for the physical environment. ${ }^{34}$ While $40 \%$ of managers were unaware of the concept of CSR, (almost) all recognized the responsibilities that we here equate with 'CSR' (see the four-dimensional approach above).

Yet again, only $35 \%$ of managers stated that these firms had implemented codes of conduct or certified management systems, and only $30 \%$ prepared CSR reports (Jeppesen et al. 2012). There are two explanations for these low figures compared to the perception of responsibilities.

\footnotetext{
${ }^{34}$ Most do not receive support from MNCs or suppliers to engage in formal CSR practices, as explained earlier.
}

First, MNC buyers may choose to turn a blind eye to their SMEs' existence so the MNCs do not have to enforce compliance. Second, most SMEs have very small profit margin, and thus cannot afford to comply even if they are aware of CSR.

Beyond the figures, however, qualitative evidence shows that many are very conscious of and have complied with some standards or 'corporate buyer's demands' in order to be able to export. For instance, one manager from a medium-size company said that their orders must meet the Eco Tex standard for the EU market, otherwise they cannot export. Another manager expressed this necessity as follows: 'CSR means whatever the buyers impose; if we don't comply, we can't export the products that we assembled/manufactured.'

Second, since most foreign suppliers and MNCs supply their own fabrics and accessories and also demand consistent quality standards and on-time delivery (critical conditions for profit maximization), they have no need to require codes of conduct compliance. Many Vietnamese SME managers complained that the foreign suppliers and MNCs put pressure on them to keep prices stable, even when input costs go up, at the expense of the workers: 'If the raw material prices increase, our customers (the MNCs) will pay for it, but they do not raise subcontract price for our workers. The reason is that they provide the raw materials, so they are willing to raise prices for their own products, but not for workers' wages' (a manager from a medium-size garment firm).

However, such low statistics on formal compliance with codes of conduct do not mean that managers do not care about labor standards and working conditions or environments. Viewed through a stakeholder perspective, we found that SMEs' owners have broad concerns for many stakeholders. Over $60 \%$ of the managers we interviewed stated that their main responsibility is to be a 'corporate citizen,' while only half stated that 'profit' is the main responsibility of the firm (Jeppesen et al. 2012). More than nine out of ten considered 'customers' (corporate buyers) and 'workers' to be the most influential stakeholders. The owner of a small leather factory said: 'Because they (the workers) determine the quality of our products.' Another garment-factory owner said: 'If workers are careful and produce good-quality products that receive no complaints from our partners (customers/buyers), the company will not be negatively affected.' We found that most managers place a high value on stable employment and recognize the relationship between workers' skills and product quality, especially in firms that produce for export. Moreover, given the labor fluctuations explained in the basic empirical findings section, many managers understand the significance of workers for their enterprises' commercial viability and on-time delivery to be vital for subcontracting work. 
Table 4 Knowledge of CSR and perception of responsibilities of SMEs among interviewed managers in the TGF industry in Vietnam

\begin{tabular}{lllll}
\hline $\begin{array}{l}\text { Topic } \\
\text { respondent }\end{array}$ & $\begin{array}{l}\text { Know } \\
\text { 'CSR' }(\%)\end{array}$ & $\begin{array}{l}\text { Responsible for physical } \\
\text { environment }(\%)\end{array}$ & $\begin{array}{l}\text { Responsible for labor standards } \\
\text { and working conditions }(\%)\end{array}$ & $\begin{array}{l}\text { Responsible for working } \\
\text { environment (OSH) }(\%)\end{array}$ \\
\hline Managers & 60 & 90 & 100 & 100 \\
\hline
\end{tabular}

Source Jeppesen et al. (2012)

Many were conscious of the significance of a living wage and decent working conditions, coming up with initiatives and informal practices to assist workers. For instance, most provide 'wage advancement' in the form of small loans. In six SMEs, of which four manufactured for export and two for the domestic market, the working atmosphere was often described as 'like families,' in which most owners expressed personal awareness of their responsibilities toward their workers, the surrounding communities and the environment. These norms have been practiced by the locals long before the introduction of CSR to Vietnam. If we respect the "southern context," then we need to consider these die-hard cultural practices in their own terms/rights. So, in spite of the spread of global capitalism, not all practices become homogenized in the name of "CSR practices," but they exist in their own right.

Turning to workers' perspectives, while most workers did not understand the formal definition of CSR, the majority was conscious of and expected to receive proper labor standards which overlap with managers' cognition discussed above. Surprisingly, the majority of interviewed workers interpreted CSR as a set of factory regulations with which to comply-such as working hard and following the rules-not employers' responsibility to improve labor standards and working conditions. In other words, the workers evaluate themselves based on how they meet the standards set by management, instead of evaluating how management implements and enforces labor standards and working conditions. So, on the question 'Whether they are satisfied with the code of conduct,' one needs to interpret these statistical findings as workers' satisfaction with 'company regulations,' not codes of conduct. In particular, when nearly eight out of ten workers said 'satisfied, ${ }^{35}$ we need to interpret that as the majority of the interviewed workers being satisfied with their compliance with company regulations.

There are several interpretations of this misunderstanding. First, it could be a win-win situation: workers' intuition to comply with safe working environment for mutual benefits with management and to make the company a

\footnotetext{
35 About one in six said 'neutral,' and very few were unsatisfied.
}

better place to work. Second, most company regulations are about health and work-safety stipulations, not about labor standards. For example, the $5 \mathrm{~S}$ system (introduced in many Japanese-owned factories), a part of the Lean Manufacturing system, is a five-phase methodical way to organize work practices: Sort, Straighten, Sweep, Standardize, and Sustain. While these practices can benefit workers in terms of a safe workplace, they are not about corporate responsibilities to workers such as decent wages and benefits.

Very few workers correctly mentioned employers' responsibilities toward them (as intended by CSR). Only about one out of thirty mentioned that the company had a code of conduct and needed to 'inspect code of conduct' for workers' benefits. One female worker in a medium-size garment factory said: 'It is to the workers' benefit that the code of conduct and company regulations be inspected.' A male worker from a small garment factory said: 'I don't know if there are any regulations. Seemingly there is no code of conduct.' Few recognized the absence of employers' responsibility to improve labor standards and working conditions. Another male worker from a small garment firm sharply pointed out: 'Regulations require punctuality, good maintenance of machines, no shouting. Sick leave should be approved before being taken. There are benefits for old-timers and seniors. Workers are required to attend monthly meetings. Employer's responsibility is not mentioned (authors' emphasis).

Workers clearly articulated their concerns about labor standards and working conditions as key parts of CSR. They are mostly concerned with stable and livable incomes with job security, proper benefits, and allowances. In particular, the median wage of 125 TGF workers is about 3 million VND (about US \$144 at the time of writing). While this level is higher than the government-stipulated minimum wage, it is still not a liveable wage in Vietnam. ${ }^{36}$ When asked 'what would be a liveable wage,' both female and male workers responded that it would be around 4

\footnotetext{
36 The median wage is the same for both female and male TGF workers. We have used the exchange rate of $1 \mathrm{USD}=20,794.00$ VND as of 15 March 2012. At the time of writing, the governmentstipulated monthly minimum wage is 2 million VND in Ho Chi Minh City and 1.78 million VND in non-metropolitan areas (Tran 2007).
} 
million VND, which is considerably higher than the median take-home wage.

Most workers are concerned about the basic labor standard issues: pay and benefits. For instance, a female worker in a medium-size garment company said: 'Guaranteed basic pay,' while another female worker stated; 'Get paid regularly on the 12th, advance pay on the 25th.' Yet another female worker expressed: 'I feel safe thanks to the social, health and unemployment insurance,' while a male worker said; 'Pleasant work. High and stable salary.'

But non-wage concerns are also important. A male worker in a medium-size textile company expressed: 'Job security. Flexible hours. Allowances for responsibilities and perfect attendance are helpful for our living conditions' and a female worker said: 'Company loans available; free meals; doctor's bills are paid by company.' Workers expressed the needs for good working relations with their owners/managers and co-workers, as well as genderspecific rest breaks, and time flexibility (especially significant for young migrant workers). They praised the conditions when they were treated with respect by their employers and enjoyed harmonious working relations with their fellow workers. Among the examples were the following quotes. A female worker from a medium-size garment company stated: 'What is most important is the close relationship between the owner and the workers; the owner's concern about workers' well-being.' A female worker from another medium-size garment company expressed that 'The owner treats me in a kind and caring way. Friendly environment.' Similar observations were stated by a female work in a medium-size textile company: 'Pleasant working atmosphere. Co-workers are like brothers and sisters in the same family.' A final example is a female worker in another medium-size garment company, who expressed her appreciation: "There is always freedom here. Workers are allowed to talk at work.'

In contrast to these (positive) statements, the workers spoke up when they were not being treated with respect. A male worker in a small garment company stated as follows: 'The manager is very rude. He shouts at workers at any time, using very rough words. The workers who learn Korean recognize these rough words.' Many female workers quoted the following stipulations for women mentioned in the Labor Code (such as paid breaks at work during menstruation cycles and pregnancy) as well as with the words of a female worker from a medium-size garment company: 'Insurance, Tet bonus and special policy for female workers.' While another female worker mentioned; 'Free lunch. Social, health, unemployment insurance... Special policy for female workers.'

Interestingly, having time flexibility is one of the most often-cited reasons by both female and male workers for them to remain with a company. As most workers are young and many are migrants, they have family obligations and need more education, so it is important as highlighted by a male worker from a small garment company to have 'Permission to take time off for family matters': Or, as stated by another male worker from a small shoe company, it is positive to have 'Flexible hours; Good relationship between owner and workers.' A female worker in a medium-size garment company expressed that 'Permission to take time off is the most important factor because I am a student and am doing part-time job'; while a male worker in a medium garment factory said: 'Late arrivals at work are tolerated. In other companies, late workers would be reprimanded.'

But what drives these intertwining cognitions of labor and management in the context of Vietnam?

\section{The Meaning of Normative Systems in Vietnam}

The "market economy with socialist orientation" in oncesocialist Vietnam, provides a context for workers' expectations of the socialist contract-or a sense of entitlements that workers used to have under the socialist regime such as job security and good benefits. At the cultural level, workers also expected to be treated with respect and kindness and be given flexibility, even when the pay was not high.

We found evidence that most managers/owners in these SMEs were reminded of, and thus responded to, these workers' expectations, at times with compassion toward their workers' needs. But there is another explanation for management's accommodation: the need to have a reliable workforce for their businesses to survive in a tight labor market. As such, the Vietnamese SME managers in this mixed system (market socialism) may have behaved with profit-maximizing behavior, similar to those in the market system with economic concerns - such as costs, wages, and job security.

All the interviewed managers expressed awareness of and engaged in informal cultural practices. Most factories-small or medium - uphold cultural practices that date back to the socialist era (before the market reforms of the late 1980s), including the 13th month's pay (or bonus) for the Vietnamese Lunar New Year, days-off for cultural events and holidays, short-term leaves for sickness and family affairs (such as weddings and funerals), small loans or advances for workers, donations (money and in-kind contributions to local communities and organizations), and cultural events and celebrations for worker entertainment (newspapers, sports events, musical entertainment, cable $\mathrm{TV}$, and access to the internet). A manager at a mediumsize garment company said: 'Whenever migrant workers from the south [i.e., provinces to the south of Ho Chi Minh 
City] have funerals, weddings, or death anniversaries, we have to allow them to go back to their home towns/villages.' Another manager at a small garment company confirmed: 'Workers still receive payment for their days off to attend to family affairs such as funerals and weddings, unless they take days off without permission.' A small textile owner said: 'We have the Tet (Vietnamese Lunar New Year) bonus.'

Some managers clearly recognized the importance of different religious, regional, racial, and ethnic practices: 'Some are Buddhists, some are Catholics, and these things have some influence' (a manager from a medium-size garment company). In some multi-ethnic companies, mutual assistance does exist: 'The company's workers include both Vietnamese and [ethnic] Chinese. The working environment has family-like elements. There are Chinese traditional and cultural practices which treat employees like family members. Mutual assistance does exist' (a manager from a medium-size garment company).

From the workers' perspective, most interviewed workers had expected to receive entitlements such as job security, stable and livable pay, and respect as part of the legacy of socialist Vietnam. They appreciated it when management allowed flexible working hours, especially important for working mothers, and there was a respectful atmosphere at work. Also, workers at this particular medium-size garment company appreciated the understanding of the owner, who himself had moved up from the rank-and-file. A manager at this factory shared this about her boss: 'The factory owner was a worker himself for twenty years, so he very much understands and empathizes [with workers]. He [the company owner] realizes that if management treats workers well, then they will work hard in return.'

Moreover, we need to bring in the effects of the norms of transnational private regulation by way of 'buyers' or third-party auditors mostly checking medium-size (not small) factories that manufacture for export. The effects are mixed. On the one hand, we found that most of these regulations tend to focus on the quality and safety of the products for the end consumers in developed countries, not necessarily for workers and their conditions, as discussed earlier. For the companies that have to comply with these standards, most owners had to absorb the costs, as in this case: 'When faced with very strict buyers' auditing of our final products, we had to spend some money to make sure that our products are up to their [quality] standards' (the female head of personnel department/accountant/union in a medium-size garment company). On the other hand, as discussed above, the norms and standards of private buyers' regulations can benefit both labor and management. There may be an overlap in ensuring both product quality and decent and safe working conditions.

\section{Discussion}

On the one hand, Scott's three-pillar framework provides an analytical lens to conduct a bottom-up analysis of the meaning of CSR to both workers and managers and to interpret the case of Vietnam. On the other hand, Scott's framework lacks power relations analysis, which is crucial to SMEs at the bottom rung of the global supply chains for the textile and garment industries. However, we have overcome this weakness by relying on the insights emanating from on-the-ground voices of SME owners and workers.

First, with regard to improving labor standards, we found an intimate connection between norms and cognition on the part of both Vietnamese managers and workers. Managers are accommodating to workers for two reasons: they respond, first, to workers' social contract (or socialist normativity) and cultural expectations and, second, to the tightness of the labor market. Pay-day advances ensure that migrant workers have to stay at least through one more pay cycle, and small concessions (letting employees talk while working, etc.) may be a way of keeping workers from leaving in search of a better work situation. On the other hand, many workers negotiate directly with their SME bosses on non-wage issues such as flexible working hours, sick leave, time off for family matters, and the 13th-month bonus. These benefits are very important labor-standard issues that are especially significant when workers' official salaries do not reach a standard for a living wage, making overtime a necessity.

The use of "informal practices" gives us a way to react to the mainstream CSR understanding, yet be able to respect cultural practices in Vietnam that existed long before the introduction of western CSR initiatives to Vietnam in the early 2000s. So, in terms of informal practices, managers and workers share long-lasting cultural norms, expectations, and socialist practices, and expect proper implementation of the Labor Code and to treat each other properly (See Table 5: Summary of Findings). In the Vietnamese cultural context, for instance, most workers would expect to receive a lump-sum Tet bonus (often in the amount of one month of salary, aptly called 'the 13thmonth salary') and short-term leave for important family obligations (such as weddings and funerals). These expectations are articulated and reinforced by the normative system and lead managers to undertake such practices.

The divergence in the understanding of owners/managers and workers on the meaning of CSR has mixed effects. While this could be interpreted as workers' intuition to comply with safe working environment for their own benefits, corporations need to be held accountable for their responsibilities to workers such as decent wages and benefits. 
Table 5 Summary of findings of CSR practices from perspectives of workers and managers/owners

\begin{tabular}{|c|c|c|c|}
\hline & Regulatory (public and private) & $\begin{array}{l}\text { Cognitive (shared conceptions and } \\
\text { social knowledge) }\end{array}$ & $\begin{array}{l}\text { Normative (formal codes, industry } \\
\text { standards, societal views of CSR, cultural } \\
\text { practices) }\end{array}$ \\
\hline Workers & $\begin{array}{l}\text { Many }(60 \%) \text { recognize labor inspection is } \\
\text { lacking } \\
\text { Many recognize more rigorous environmental } \\
\text { (and food safety) regulation than labor } \\
\text { regulation } \\
\text { Many did not wear masks, even when they are } \\
\text { issued, due to hot, poorly ventilated } \\
\text { conditions }\end{array}$ & $\begin{array}{l}\text { Few }(10 \%) \text { understand the formal } \\
\text { definition of CSR } \\
\text { Most }(80 \%) \text { interpreted company } \\
\text { regulations as codes of conduct } \\
\text { (CoC) } \\
\text { Most expected rights/benefits from } \\
\text { Labor Code } \\
\text { Workers' requests: } \\
\text { Flexible working hours } \\
\text { Livable wage, not minimum wage } \\
\text { Good working relations with } \\
\text { owners/managers }\end{array}$ & $\begin{array}{l}\text { Cultural practices (13th month bonus, } \\
\text { patriarchal relations especially in small } \\
\text { shops) } \\
\text { Socialist expectations (job security and } \\
\text { stability) } \\
\text { Labor Code expectations (labor standards) }\end{array}$ \\
\hline $\begin{array}{l}\text { Managers/ } \\
\text { owners }\end{array}$ & $\begin{array}{l}\text { State and quasi-state play key role in } \\
\text { environmental regulation } \\
\text { Transnational private regulation } \\
\text { Many complained about high certification fees } \\
\text { and inspection fees } \\
\text { Time-consuming reports } \\
\text { No assistance from first-tier suppliers or the } \\
\text { government for certification and compliance }\end{array}$ & $\begin{array}{l}\text { Most }(90 \%) \text { understand unequal } \\
\text { power relations in the global supply } \\
\text { chains } \\
\text { Most SME domestic producers are } \\
\text { not certified } \\
\text { Third tier cannot afford to pay } \\
\text { certifications }\end{array}$ & $\begin{array}{l}\text { Most ( } 85 \%) \text { SME export companies have } \\
\text { CSR certifications } \\
\text { Shared with workers the above norms and } \\
\text { cultural practices } \\
\text { Contradiction of 'small loans' (or } \\
\text { advances) to workers } \\
\text { Contributions to local communities, } \\
\text { households, temples, churches }\end{array}$ \\
\hline
\end{tabular}

Source The authors

Second, in the realm of regulation, we found mixed effects of three levels of regulation. State regulation and transnational third-party monitoring are not always effective, which has given rise to 'invisible' SME subcontractors at the bottom rung of the global supply chain. While government industrial policies which invest in learning and skills training in the TGF sector can improve wages and working conditions (Tran 2012), state regulation can disadvantage SMEs by increasing inspection costs and requiring them to produce time-consuming reports.

As shown in Table 5, the state-in both its formal and quasi-formal roles-continues to play a vital role in both labor and environmental regulations. But workers correctly pointed out that labor inspections have been more lax compared to environmental inspections. This again shows the prioritized attention going to the quality of the products or the public perception of waste, not to the workers' welfare. We found that many workers did not comply with some crude measures of protection—such as wearing protective masks - on the shop floor. But workers' compliance would depend on management's compliance (with CSR) in providing workers with decent working conditions in the first place. For instance, the temperatures in TGF factories are often high and workspaces often lack proper ventilation, thus even when workers recognize the health benefits of wearing masks, they may choose not to wear them even when available ${ }^{37}$ simply because it is unbearable to work in such conditions.

Moreover, transnational private monitoring - such as third-party global monitors or auditors and the Japanese buyers' $5 \mathrm{~S}$ System (whose services are most likely paid for by the MNCs and/or their suppliers) - tend to focus on the consistent quality of the products, not the well-being of workers. Moreover, unequal power relations in global supply chains are demonstrated by MNCs and their East Asian suppliers who provide their own fabrics and accessories (from external sources) to their SME subcontractors and do not list the SMEs in their supplier list, thus not requiring codes-of-conduct compliance.

The third insight concerns the contradictions of the often-cited 'small loans' (see Table 5), demonstrating the unequal gender relations in SME settings, where most bosses are men. In reality, these 'short-term loans' are merely advances to workers that management immediately deduct from workers' next pay checks, so the latter receive a lesser amount on pay days. While these small advances are essential so that workers can pay for their basic necessities, medical expenses, or trips to home for family matters, this common practice reinforces the paternal relationships, perpetuates the cycle of indebtedness and

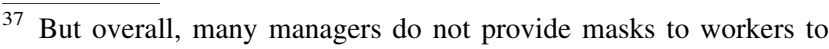
save costs.
} 
precarious hand-to-mouth existence of many workers, and does not solve the root cause of the shortages: non-livable wages.

\section{Concluding Remarks}

Our study with concrete fieldwork interviews forefronts the voices of SME managers and workers to fill the gap in the literature on CSR in SMEs, an area with limited contributions. Though CSR policies often promote livable wages and benefits, safe and clean working conditions, and a sustainable environment, implementation of CSR practices comes with a cost. Our findings show that, ultimately, the managers and the workers in these SMEs absorb the costs or the CSR practices are not implemented because the business case for CSR in SMEs cannot be identified or because the western concept of CSR is not understood by managers and workers.

Showcasing the voices of managers and workers from SMEs in once-socialist Vietnam, a particular "Southern perspective," reveals what CSR really means to them: socially responsible practices and expectations that had been happening long before the arrival of CSR as a western concept. These two key stakeholders recognize the shared conceptions of socially and culturally responsible behaviors in SME settings, with many workers interpreting (and complying with) factory regulations as if they were codes of conduct.

We are conscious of the mixed results of some informal practices-informed by social and cultural expectationsthat might perpetuate dependency and differential power relations between employers and employees. But we found that in spite of the spread of global capitalism-or the integration of Vietnam into the global supply chains since the late 1990s - shared understanding, norms and socialist values do not become homogenized; they sustain. On the one hand, it is true that 'small loans' or 'wage advancement' given to workers-to be deducted in the next paycheck-can perpetuate dependency toward a particular SME owner who needs to keep workers in a tight labor market for SMEs. On the other hand, it is not a "race-tothe-bottom": management could not sacrifice all standards when global competitive pressures demand it, because workers in these SMEs do have some bargaining power to demand other concessions from management, as shown in their interviews: flexible working hours (important for young women taking care of their families), livable wages (higher than the minimum wage), and good working relations with both management and co-workers. These worker requests are also dictated by shared understanding and practices in existence long before CSR's arrival to Vietnam.
The emphasis of the CSR agenda tends to be dictated by and biased toward the interests of MNCs, as pointed out by the critical perspectives presented above. Such direction shapes the language and application of formal and informal practices (Blowfield and Frynas 2005) and explains why we found widespread informal and limited formal CSR practices among SMEs in Vietnam. This study demonstrates the unequal power relations in the global supply chains, with MNCs showcasing CSR to appease consumers but placing the onus of both practice and proof onto those on lower tiers, which increases the costs of doing business for their suppliers and the SME subcontractors, leaving less for workers' wages. Most interviewed SME managers-in third or the fourth tier of the global value chains-expressed knowledge about CSR but stated that they cannot afford to be certified in codes of conduct, to remedy the 'code violations,' or to produce time-consuming 'sustainability/responsibility reports.' SME management perspectives clearly point to the MNC's failure to share the costs of implementing and monitoring CSR practices.

What can be done to improve these conditions in Vietnam? It takes both domestic and international stakeholders to address these concerns. First, MNCs need to share the CSR costs with the SMEs, because after all, it is corporate social responsibility to implement the stated intention of CSR to improve conditions in SME factories, in conjunction with the shared understandings, norms, and practices of workers and managers in Vietnam. International NGOs are to be commended for their constructive works, such as the ongoing efforts of Action Aid to empower local villagers in Vietnam to improve their working and physical environments. Second, both workers and managers pointed to the need for stronger state enforcement of the Labor Code. A collaboration of private and state regulation could be a win-win outcome for all stakeholders: for instance, the MNCs can finance impartial NGOs, with good track record on transparency, to monitor labor standards in the SMEs working in their supply chains. Third, MNCs should offer and finance the costs of training courses on codes of conduct at SME level so that workers can have a proper understanding of their rights promised by the stated CSR intentions in order to empower their bargaining positions.

Acknowledgments We would like to acknowledge the French development Agency AFD (Agence Francaise du Developpement) for financing the study from which we draw data for this article. We are also indebted to the Vietnamese team that supported us throughout this whole process, including endless hours in the collection and processing of field data as well as follow-up questions. The team included Huynh Thi Ngoc Tuyet, Nguyen Minh Chau, Tran Bao Ha, Nguyen Cuc Tram, and Nguyen Vu from the Sustainable Development Research Institute in the Southern Region, Ho Chi Minh City, and Doan Thi Kim Khanh, ESL and Citizenship Teacher from Boat People SOS Organization. Laura Jakobeit provided invaluable support through her assistance with data analysis as the then research assistant 
at the Centre for Business and Development Studies, Department of Intercultural Communication and Management, Copenhagen Business School. We are grateful to Joe Lubow who provided excellent copyediting assistance throughout the editing process to the final version and to Andrew Crabtree, who provided the last round of critical and thoughtful copy-editing before the final submission. Last, but not least, we are grateful to the two reviewers, who provided valuable and insightful comments, which enabled us to bring the article to its present stage.

\section{Appendix}

Appendix 1: Detailed Information on Categories of Questions Asked to 20 Interviewed SMEs (Managers and Workers) in the TGF Sector in Vietnam

Based on this literature, we used a four-dimensional approach to explore formal and 'informal' CSR practices when interviewing representatives from SMEs. The formal CSR practices include (1) physical environment, (2) working environment, and (3) labor standards/working conditions. The informal CSR practices include (4) informal arrangements between management and employees (such as loans, various types of leave) and support to the local communities and others (e.g., in the form of donations of money or in kind, or in personal involvement).

On formal CSR practices, we inquired about the systems, code certifications, and compliance activities in three areas: labor standards, the working environment, and the physical environment. With respect to informal CSR practices, our culturally sensitive questions covered Vietnamese cultural practices embedded in their changing politico-economic contexts, since the market reform in the late 1980s and the historical legacy. For example, we inquired about 'informal assistance to workers' and included possible responses such as loans, different types of leave, and others. On 'support to local communities and organizations,' we included responses such as monetary and/or in-kind contributions to local religious centers, schools, youth clubs, sports clubs, and other community-based organizations, and goals. On 'involvement in community work,' we elicited open-ended responses that revealed a wide array of cultural- and country-specific activities by managers and workers in Vietnam.

In particular, to explore how SME managers understand various formal practices such as codes of conduct, we asked 20 questions related to the cognitive level which addressed all relevant stakeholders, both internal and external to the SMEs, based on the exploratory component. We then asked 35 questions addressing both the cognitive and regulatory levels to investigate how managers understand and actually perform their company responsibilities, given the historical legacy and cultural context (informal practices). These questions elicited the country-specific contexts of modern-day socialist Vietnam. To show relations between SME managers and workers, we asked five questions. Moreover, we asked 21 questions to reveal the perspectives of other relevant stakeholders and their impacts on labor-management-state relations, such as corporate buyers, first-tier and second-tier suppliers, government and labor union officials, local communities, NGOs, and other global actors.

First, we interviewed the managers based on a qualitative, in-depth interview format for owners/managers asking the categories of questions mentioned above. Second, we interviewed 125 workers in 14 SMEs, using three types of semi-structured questionnaires for focus-group, individual and in-depth interviews. The Vietnamese team was able to do this thanks to their extensive ongoing contacts with local labor unions and government officials. Third, we conducted follow-up interviews with managers using the more quantitative or structured questionnaire that focused on changes over time (in five years) in labor standards and environmental aspects.

Appendix 2: A Note on the Application of Rawls' Arguments to Vietnam and this Study

Rawls' theory of justice is premised on a liberal society in which the citizens are free with basic equal rights and the political system is democratic and legitimate. His argument of "justice as fairness" is based on a "well-ordered society"; the basic structure of this society is characterized by the main political and social institutions being publicly known "to satisfy principles of justice." In this wellordered democratic society, Rawls argues that the citizens develop their moral powers and become fully cooperating members: understand and apply the publicly recognized principles of justice, and adjudicate their claims of political right on those political institutions (Rawls 2001, pp. 8-9, 57). However, the one-party Socialist Vietnam is not a well-ordered democratic society. Its basic structure, sanctioned by the Eighth Party Congress in 1996 as a "socialist state governed by the rule of law," is undermined by the Communist Party government which has not respected the supposed separation of powers (the Politburo, the National Assembly, and the Judiciary). There is no moral division of labor between the branches of the government and the citizens they purport to represent, because the state arbitrarily has enforced some laws and not others, while the citizens have had to fight for their basic rights (Tran 2013, pp. 3-6). The socialist legacy of ensuring equity, or equal distribution of wealth and income, has some connection to Rawls' second part of the second principle of justice: the greatest benefit of the least-advantaged members of society (the difference principle) (Rawls 2001, pp. 42-43). But fundamental contradictions inherent in Vietnam's "market 
economy with socialist orientation" have greatly diminished, if not prevented, the fulfillment of this sense of justice and equity on behalf of its citizens in socialist Vietnam (Tran 2013, pp. 261-289).

In thinking further about Rawls' two principles of justice (pp. 42-43): the first principle does not apply to Vietnamese citizens as each person does not have "the same indefeasible claim to a fully adequate scheme of equal basic liberties." The Communist Party members and former government officials (Party members) have power, privileges and access not accessible to all citizens. In the context of CSR, public regulation of CSR is controlled by state and quasi-state institutions as discussed in the Meaning of Regulatory System in Vietnam section. The second principle of "offices and positions open to all under conditions of fair equality of opportunity" also does not apply to Vietnam since, in reality, political power is dominated by Communist Party members: over $90 \%$ of seats in the National Assembly of Vietnam are held by Communist Party members (only a minority were independent members).

\section{References}

Amine, L. S., \& Staub, K. M. (2009). Women entrepreneurs in subSaharan Africa: An institutional theory analysis from a social marketing point of view. Entrepreneurship and Regional Development, 21(2), 183-211.

Arnold, D. G., \& Hartman, L. P. (2006). Worker rights and low wage industrialization: How to avoid sweatshops. Human Rights Quarterly, 28, 676-700.

Blackman, A. (Ed.). (2006a). Small firms and the environment in developing countries: Collective impact, collective action. Washington D.C.: Resources for the Future.

Blackman, A. (2006b). Introduction. In A. Blackman (Ed.), Small firms and the environment in developing countries: Collective impact, collective action (pp. 1-19). Washington D.C.: Resources for the Future.

Blowfield, M., \& Frynas, J. D. (2005). Setting new agendas: Critical perspectives on corporate social responsibility in developing countries. International Affairs, 81(3), 499-514.

Dimaggio, P. J., \& Powell, W. W. (1983). The iron cage revisited: Institutional isomorphism and collective rationality in organizational fields. American Sociologist Review, 48, 147-160.

Fassin, Y. (2008). SMEs and the fallacy of formalising CSR. Business Ethics: A European Review, 17(4), 364-378.

Fox, T. (2005). Small and medium size enterprises (SMEs) and corporate social responsibility: A discussion paper. London: International Institute for Environment and Development.

Freeman, E. R. (1984). Strategic management: A stakeholder approach. Boston, MA: Pitman.

Frynas, J. G. (2009). Corporate social responsibility in the oil and gas sector. The Journal of World Energy Law and Business, 2(3), 178-195.

Fuller, T., \& Tian, Y. (2006). Social and symbolic capital and responsible entrepreneurship: An empirical investigation of SME narratives. Journal of Business Ethics, 67(3), 287-304.
Hamm, B. (2012, July/August). Corporate social responsibility in Vietnam. Integration or mere adaptation? Pacific News, No. 38.

Hotho, J. J., \& Pedersen, T. (2012). Beyond the 'Rules of the Game': Three institutional approaches and how they matter for international business. In G. Wood \& M. Demirbag (Eds.), Handbook of institutional approaches to international business (pp. 236-273). Cheltenham: Edward Elgar.

Jamali, D., Lund-Thomsen, P., \& Jeppesen, S. (forthcoming). SMEs and CSR in developing countries. Editorial. Special issue of Business and Society.

Jamali, D., \& Neville, B. (2011). Convergence versus divergence of CSR in developing countries: An embedded multi-layered institutional lens. Journal of Business Ethics, 102, 599-621.

Jamali, D., Zanhour, M., \& Keshishian, T. (2009). Peculiar strengths and relational attributes of SMEs in the context of CSR. Journal of Business Ethics, 87(3), 355-377.

Jenkins, H. (2004). a critique of conventional CSR theory: An SME perspective. Journal of General Management, 29(4), 37-57.

Jeppesen, S. (2004). Environmental practices and greening strategies in small manufacturing enterprises in South Africa: A critical realist approach. (Doctoral Thesis). PhD Series 11-2004. Copenhagen: Department of Intercultural Communication and Management, Copenhagen Business School.

Jeppesen, S., Kothuis, B. and Ngoc Tran, A. (2012). Corporate social responsibility, competitiveness and SMES in developing countries. South Africa and Vietnam. Research Report (Focales no 16). Paris, France: French Development Agency (AFD).

Jeppesen, S., \& Lund-Thomsen, P. (2010). Special issue on 'New Perspectives on Business, Development and Society', editorial. Journal of Business Ethics, 93(supplement 2), 139-142. doi:10. 1007/s10551-010-0557-3.

Khan, R. F., \& Lund-Thomsen, P. (2011). CSR as imperialism: Towards a phenomenological approach to CSR in the developing world. Journal of Change Management, 11(1), 73-90.

Kim, J. Y. (2012). The politics of code enforcement and implementation in Vietnam's Apparel and footwear factories. World Development, 45, 286-295.

Kumari, P. (2008). Comparison of major issues pertaining to social responsibility in corporate and micro, small and medium enterprises (MSMEs) in India. Vienna: UNIDO.

Laudal, T. (2010). The global dissemination of CSR among SMEs and the level of economic development. A qualitative metasynthesis. Paper presented at the annual internationalsustainable development research conference, 30 May-1 June 2010, Hong Kong (pp. 1-28).

Lepoutre, J., \& Heene, A. (2006). Investigating the impact of firm size on small business social responsibility: A critical review. Journal of Business Ethics, 67(3), 257-273.

Luetkenhorst, W. (2004). Corporate social responsibility and the development agenda: The case for actively involving small and medium-sized enterprises. Intereconomics, 39, 157-166.

Luken, R., \& Stares, R. (2005). Small business responsibility in developing countries: A threat or an opportunity? Business Strategy and the Environment, 14(1), 38-53.

Moore, G., \& Spence, L. (2006). Editorial: Responsibility and small business. Journal of Business Ethics, 67(3), 219-226.

Morsing, M., \& Perrini, F. (2009). CSR in SMEs: Do SMEs matter for the CSR agenda? Business Ethics: A European Review, 18(1), $1-6$.

Murillo, D., \& Lozano, J. (2006). SMEs and CSR: An approach to CSR in their own words. Journal of Business Ethics, 67(3), 227-240.

Newell, P., \& Frynas, J. G. (2007). Beyond CSR? Business, poverty and social issues: An introduction. Third World Quarterly, 28(4), $669-681$. 
Peng, M. (2002). Towards an institution-based view of business strategy. Asia Pacific Journal of Management, 19, 251-267.

Peng, M. (2003). Institutional transitions and strategic choices. The Academy of Management Review, 28(2), 275-296.

Prieto-Carron, M., Lund-Thomsen, P., Chan, A., Muro, A., \& Bushan, C. (2006). Critical perspectives on CSR: What we know, what we don't know and need to know. International Affairs, 82(5), 977-988.

Rawls, John. (2001). Justice as fairness: A restatement. Cambridge, MA: Harvard University Press.

Raynard, P., \& Forstater, M. (2002). Corporate social responsibility: Implications for small and medium enterprises in developing countries. Vienna: UNIDO.

Russo, A., \& Tencati, A. (2009). Formal vs informal CSR strategies: Evidence from Italian micro, small, medium-sized, and large firms. Journal of Business Ethics, 85, 339-353.

Scott, W. R. (1995/2001). Institutions and organizations. London: Sage Publications.

Scott, A. (2000). Small-scale enterprises and the environment in developing countries. In R. Hillary (Ed.), Small and mediumsized enterprises and the environment. Business Imperatives (pp. 276-288). Sheffield: Greenleaf Publishing Limited.

Singh A., Kundu, S., \& Forstater, W. (2005). Corporate social responsibility through the supply chain: MNCs to SMEs. (Masters thesis). New York, NY: School of International and Public Affairs, Columbia University and World Bank Institute. Retrieved from http://www.sme-egypt.org/Documents/Market ing/CSR_Through_the_Supply_Chain_MNCs_to_SMEs,_May_ 2005.pdf.

Skadegaard Thorsen, S., \& Jeppesen, S. (2010). Changing course: A study into responsible supply chain management. Analysis report. Copenhagen: The Danish Ministry of Foreign Affairs/ Danida.

Spence, L., Habish, A., \& Schmidpeter, R. (2003). Responsibility and social capital: The world of small and medium sized enterprises. London: Palgrave-Macmillan.
Tran, A. N. (2007). Alternatives to the 'Race to the Bottom' in Vietnam: Minimum wage strikes and their aftermath. Labor Studies Journal, 32(4), 430-451.

Tran, A. N. (2011). Corporate social responsibility in socialist Vietnam: Implementation, challenges and local solutions. In A. Chan (Ed.), Labor in Vietnam. Singapore: Institute of Southeast Asian Studies.

Tran, A. N. (2012). Vietnamese textile and garment industry in the global supply chain: State strategies and workers' responses. International Journal of Institutions and Economies, 4(3), 123-150.

Tran, A. N. (2013). Ties that bind: Cultural identity, class and law in flexible labor resistance in Vietnam. Ithaca, NY: Southeast Asia Program (SEAP), Cornell University Press.

Tran, A. N., \& Norlund, I. (2014). Globalization, industrialization and labor markets in Vietnam. Journal of the Asia Pacific Economy, 20(1). Special issue: Globalization, industrialization and labour markets in East and South Asia: Essays in honour of Melanie Beresford (pp. 143-163).

UNEP. (2003). Big challenge for small business: Sustainability and SMEs. Industry and Environment, 26(4), 7-9.

Vives, A. (2006). Social and environmental responsibility in small and medium-sized enterprises in Latin America. Journal of Corporate Citizenship, 21, 39-50.

Whalley, S. (2000). What are 'Appropriate' systems for assessing environmental risks and performance in small businesses? In R. Hillary (Ed.), Small and medium-sized enterprises and the environment. Business imperatives (pp. 119-127). Sheffield: Greenleaf Publishing Limited.

Williamson, D., Lynch-Wood, G., \& Ramsay, J. (2006). Drivers of environmental behaviour in manufacturing SMEs and the implications for CSR. Journal of Business Ethics, 67(3), 317-330.

World Bank. (2003). Corporate social responsibility practice: Strengthening implementation of corporate social responsibility in global supply chains. World Bank Group: Washington D.C. 